CHAPPER, M.; BACARIN, M.A.; PEREIRA, A.S.; TERRIBLE, L.C. Carboidratos não estruturais em tubérculos de dois genótipos de batata armazenados em duas temperaturas. Horticultura Brasileira, Brasília, v. 20, n. 4, p. 583-588, dezembro 2002.

\title{
Carboidratos não estruturais em tubérculos de dois genótipos de batata armazenados em duas temperaturas ${ }^{1}$
}

\author{
Marilice Chapper $^{2}$; Marcos Antonio Bacarin $^{3}$; Arione da Silva Pereira ${ }^{4}$; Levi Carina Terribile ${ }^{3}$ \\ ${ }^{2}$ UFPEL, CAVG, C. Postal 460, 96.010-900 Pelotas-RS; ${ }^{3}$ UFPEL, Depto. Botânica, C. Postal 354, 96.010-900 Pelotas-RS; ${ }^{4}$ Embrapa \\ Clima Temperado, C. Postal 403, 96.001-970 Pelotas-RS. Bolsista CNPq; E-mail: arione@cpact.embrapa.br
}

\section{RESUMO}

Observa-se, em tubérculos de batata submetidos a baixas temperaturas, aumentos nos teores de açúcares redutores, os quais, no momento da fritura, provocam o escurecimento do produto, inviabilizando-o comercialmente. Avaliou-se a concentração de carboidratos em duas cultivares de batata (Pérola e Atlantic), armazenados em duas condições de temperatura. Os tubérculos foram produzidos nos cultivos de outono e primavera de 1999. Logo após a colheita, os tubérculos foram divididos em dois lotes, padronizados quanto ao tamanho, armazenados durante 40 dias, em condições de ambiente $\left(21 \pm 3^{\circ} \mathrm{C}\right.$ para a produção de outono; $24 \pm 2^{\circ} \mathrm{C}$ para a produção de primavera) e sob refrigeração $\left(2 \pm 1^{\circ} \mathrm{C}\right)$. Em intervalos regulares de dez dias, iniciando-se na data de armazenamento dos tubérculos (tempo zero), coletaram-se amostras de duas regiões dos tubérculos (central e periférica), para a determinação dos teores de amido, sacarose, carboidratos solúveis totais e açúcares redutores. Os teores de amido não foram alterados pelas condições de armazenamento, enquanto que os demais carboidratos apresentaram elevação quando os tubérculos foram submetidos à refrigeração, principalmente entre 10 e 20 dias de armazenamento. Contudo, as variações em respostas à baixa temperatura apresentaram-se diferenciadas em função do genótipo, da época de cultivo das plantas e das regiões dos tubérculos.

Palavras-chave: Solanum tuberosum, açúcares redutores, adoçamento, armazenamento.

\begin{abstract}
Non-structural carbohydrates in potato tubers of two genotypes stored under two temperature conditions

Potato tubers exposed to low temperature increase the reducing sugar content, that during the frying process causes the darkening of the product, losing its commercial value. The non-structural carbohydrates content of two potato cultivars (Perola and Atlantic) stored at two temperature conditions was evaluated. Tubers were produced at Embrapa Clima Temperado, Pelotas, (Brazil), in autumn and spring crops of 1999. Immediately after harvest, the tubers were divided in two lots, standardized as regards to the size and stored under room temperature $\left(21 \pm 3^{\circ} \mathrm{C}\right.$ for autumn production; $24 \pm 2^{\circ} \mathrm{C}$ for spring production) and cold storage $\left(2 \pm 1^{\circ} \mathrm{C}\right)$ for 40 days. Samples of two regions of the tubers (central and peripheral) were collected from the two storage conditions, at a ten-day interval, starting on the storage day of the tubers (time zero) during 40 days. In each sampling, the starch, sucrose, total soluble carbohydrates and reducing sugar content were evaluated. The starch content was not affected by storage temperature, while the other carbohydrates showed a rise in the cold stored tubers, mainly between 10 and 20 days. However, the changes due to low temperatures differed with genotype, crop season and region of the tuber.
\end{abstract}

Keywords: Solanum tuberosum, reducing sugars, low temperature sweetening, storage.

\section{(Recebido para publicação em 7 de fevereiro de 2001 e aceito em 7 de maio de 2002)}

$\mathrm{O}$ problema primário da batata associado à fritura é o escurecimento não enzimático do tecido, que ocorre sob condições de alta temperatura no momento do processamento, quando os níveis de açúcares redutores são altos (reação de Maillard). Os açúcares redutores, glicose e frutose, combinam-se com os grupos alfa amino dos aminoácidos em altas temperaturas, resultando num produto que é inaceitavelmente escuro. $\mathrm{O}$ conteúdo de açúcares redutores geralmente aceito é de $0,1 \%$ da massa fresca do tubérculo com um limite máximo de 0,33\% (Davies \& Viola, 1992).

Quando os tubérculos de batata são submetidos à baixa temperatura ocorre o acúmulo de açúcares, tornando-os impróprios à produção de batata frita (Vliet \& van Schriemer, 1960; Burton, 1989). Esta situação afeta a qualidade do processamento e consequentemente, seu valor comercial. O processo pelo qual ocorre o acúmulo de açúcares envolve a interação de muitas vias metabólicas, todavia, falta descrevê-lo em sua totalidade (Duplessis et al., 1996).

As condições de baixa temperatura resultam em acúmulo de ATP no tecido de batata e acarretam a ativação da via alternativa, respiração resistente ao cianeto, que diminui os níveis de ATP e simultaneamente incrementa as concentrações de sacarose. Essa sacarose tor- na-se o substrato da invertase ácida vacuolar que originará o acúmulo de açúcares redutores. $\mathrm{O}$ controle somente da via alternativa ou em combinação com a atividade da invertase ácida pode proporcionar informações sobre o fenômeno de adoçamento induzido pelo frio, em tubérculos de batata armazenados (Duplessis et al., 1996).

Segundo Zhou \& Solomos (1998), há uma relação temporal entre o acúmulo de açúcar e a atividade de enzimas envolvidas na interconversão amido-açúcar. Por outro lado, Ohad et al. (1971) sugeriram que a deterioração das membranas do amiloplasto a baixas temperaturas é a causa do adoçamento,

${ }^{1}$ Parte da dissertação de mestrado em fisiologia vegetal, do primeiro autor, apresentada à UFPEL. 


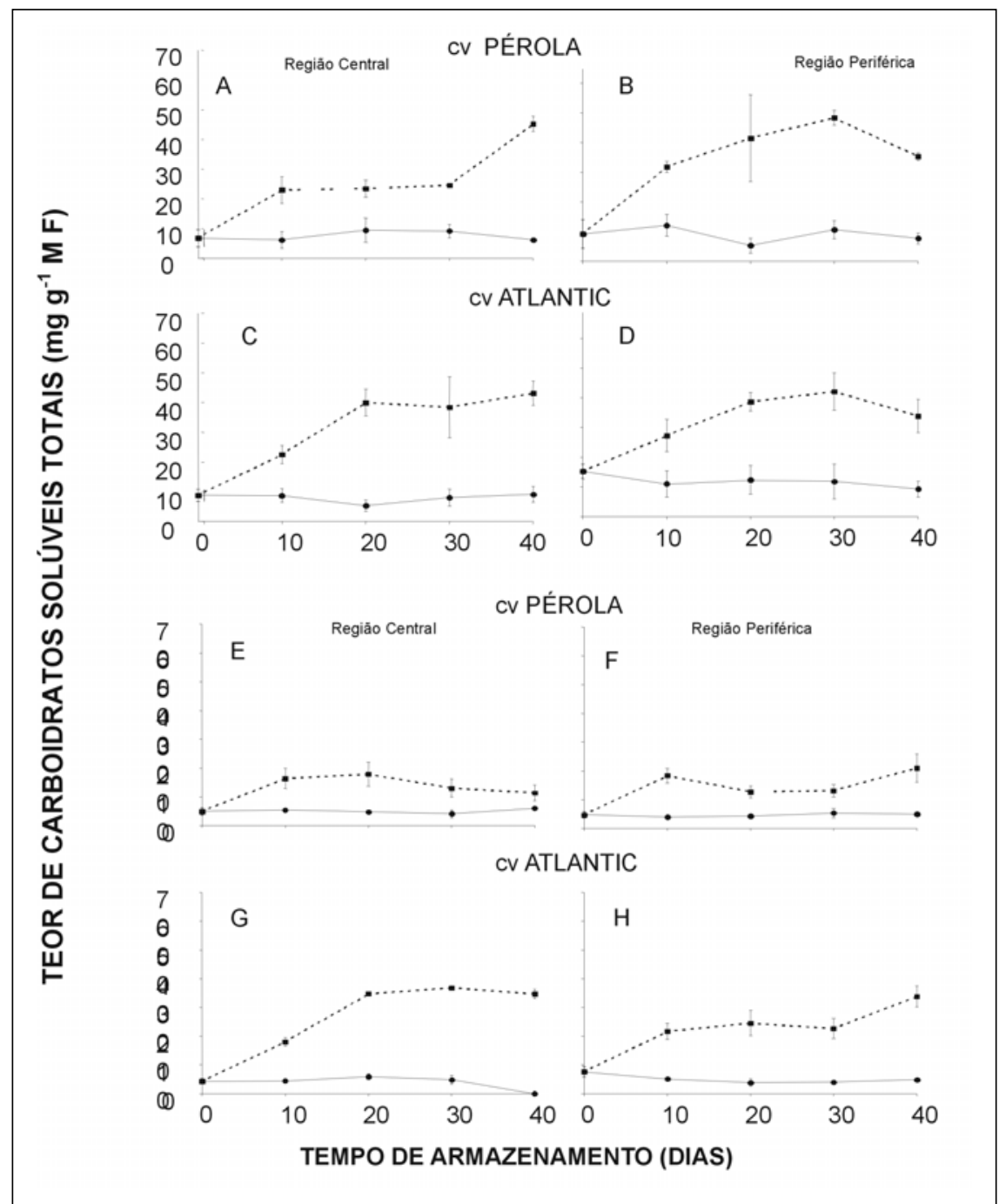

Figura 1. Teor de carboidratos solúveis totais em tubérculos de batata das cvs Pérola e Atlantic, oriundos dos plantios de outono/99 (A, B, C e D) e primavera/99 (E, F, G, e H), em função do tempo e das condições de armazenamento, [ ambiente $(3 / 4 / 4)$ e refrigeração ( - - - )]. A barra indica o desvio padrão da média. Pelotas, UFPEL, 1999.

alterando a distribuição de metabólitos entre o citossol e os amiloplastos.

Durante o adoçamento sob temperaturas baixas, o amido é a única fonte de carbono para a respiração (Isherwood, 1973) e para o fornecimento de esqueletos carbônicos para outras rotas biossintéticas (Illeperuma et al., 1998). A conversão de amido para açúcares simples é mediada, provavelmente, via fosforilase, porque a sacarose é o primeiro açúcar a se acumular quando os tubérculos são submetidos a baixas temperaturas (Barker, 1968; Isherwood, 1973). Entretanto, os produtos da metabolização hidrolítica do amido armazenados nos tubérculos, como maltose e malto-oligossacarídeos, apresentam pequeno aumento durante o adoçamento a baixas temperaturas (Isherwood, 1973). Outros fatores além da fosforilase do amido, regulam a biossíntese da sacarose a baixas temperaturas (Isherwood, 1976).

De acordo com Illeperuma et al. (1998), o incremento no conteúdo de açúcar em tubérculos de batatas é também causado por outros fatores além do frio, tais como a idade (Burton, 1982; Isherwood, 1976); o etileno e tratamentos com HCN (Solomos \& Laties, 1975) e uma variedade de práticas culturais (Sowokinos, 1990).

O objetivo do presente trabalho foi verificar os teores de carboidratos não estruturais, em tubérculos de dois genótipos de batata, mantidos sob diferentes condições de temperatura de armazenamento.

\section{MATERIAL E MÉTODOS}

Tubérculos das cultivares de batata Atlantic e Pérola foram produzidos em duas épocas de cultivo (outono e primavera de 1999), no campo experimental da sede da Embrapa Clima Temperado, situado em Pelotas ( $31^{\circ} 52^{\prime} \mathrm{S}$ e $51^{\circ} 21^{\prime}$ $\mathrm{W})$, a altitude de cerca de $50 \mathrm{~m}$. Estas cultivares foram utilizadas nos ensaios por serem recomendadas para fritura na forma de fatias ou "batata palha" (Melo, 1999; Pereira et al., 2000).

Nos dois cultivos foram realizados tratos culturais recomendados, sendo as temperaturas médias diárias inferiores a normal da região. As plantas cultivadas no plantio de outono foram expostos a 107 horas de frio $\left(<7,2^{\circ} \mathrm{C}\right)$, enquanto que os de primavera a 44 horas.

Imediatamente após cada colheita, os tubérculos foram transferidos para o Laboratório de Fisiologia Vegetal da UFPEL, e divididos em dois lotes, padronizados quanto ao tamanho. Um lote foi armazenados em ambiente sob condições naturais, cuja temperatura foi medida diariamente, obtendo-se média de $21 \pm 3^{\circ} \mathrm{C}$ para os tubérculos oriundos do plantio de outono e de $24 \pm 2^{\circ} \mathrm{C}$ para os de primavera. $\mathrm{O}$ segundo lote foi armazenado sob condição controlada de temperatura e mantido a $2 \pm 1^{\circ} \mathrm{C}$ para ambos os plantios, sempre na ausência de luz.

Amostras de tubérculos sadios foram coletadas para análise em intervalos regulares de dez dias, iniciando-se na data de armazenamento dos tubérculos (tempo zero), durante 40 dias de armazenamento, perfazendo um total de cinco coletas. As amostras foram coletadas e acondicionadas individualmente em recipientes e soluções adequadas até o momento do processamento. Em cada amostragem foram avaliados os teores de amido, sacarose, carboidratos solúveis totais e açúcares redutores.

As determinações de teores de amido foram realizadas com o resíduo dos centrifugados, após extração dos carboidratos solúveis, segundo o método descrito por McCready et al. (1950). Os teores de carboidratos solúveis totais foram determinados por meio das reações com antrona (Clegg, 1956) e os 
Tabela 1. Teor de amido (mg amido $\mathrm{g}^{-1}$ massas fresca) de tubérculos de duas cultivares batata colhidos em duas épocas de plantios e armazenados sob duas condições de temperatura. Pelotas, UFPEL, 1999.

\begin{tabular}{|c|c|c|c|c|c|c|c|c|}
\hline \multirow{3}{*}{ Plantio } & \multirow{3}{*}{ Cv. } & \multirow{3}{*}{$\begin{array}{l}\text { Condição de } \\
\text { armazenam. }\end{array}$} & \multirow{3}{*}{$\begin{array}{l}\text { Região do } \\
\text { tubérculo }\end{array}$} & \multicolumn{5}{|c|}{ Tempo de armazenamento (dias) } \\
\hline & & & & 0 & 10 & 20 & 30 & 40 \\
\hline & & & & \multicolumn{5}{|c|}{ Teor de amido ( $\mathrm{mg}$ amido $\mathrm{g}^{-1}$ massa fresca) (1) } \\
\hline \multirow{10}{*}{ Outono } & \multirow{5}{*}{ Pérola } & \multirow[t]{3}{*}{ Ambiente } & Periférica & 199,9 & 153,3 & 208,3 & 177,1 & 198,0 \\
\hline & & & Central & 254,7 & 242,1 & 85,0 & 120,6 & 181,1 \\
\hline & & & & & & & & \\
\hline & & \multirow[t]{2}{*}{ Refrigerado } & Periférica & 199,9 & 148,7 & 124,7 & 142,7 & 172,7 \\
\hline & & & Central & 254,7 & 163,0 & 102,2 & 175,0 & 144,4 \\
\hline & \multirow{5}{*}{ Atlantic } & \multirow[t]{2}{*}{ Ambiente } & Periférica & 250,5 & 215,7 & 200,5 & 166,4 & 283,7 \\
\hline & & & Central & 131,3 & 129,2 & 160,4 & 159,9 & 231,0 \\
\hline & & & & & & & & \\
\hline & & \multirow[t]{2}{*}{ Refrigerado } & Periférica & 250,5 & 215,5 & 190,2 & 252,8 & 170,5 \\
\hline & & & Central & 131,3 & 137,5 & 163,3 & 112,2 & 96,7 \\
\hline \multirow{10}{*}{ Primavera } & & \multirow[t]{2}{*}{ Ambiente } & Periférica & 198,8 & 167,2 & 185,5 & 251,7 & 239,0 \\
\hline & & & Central & 170,3 & 118,8 & 139,7 & 217,3 & 153,8 \\
\hline & Pérola & & & & & & & \\
\hline & & \multirow{2}{*}{ Refrigerado } & Periférica & 198,8 & 186,9 & 146,5 & 238,8 & 286,5 \\
\hline & & & Central & 170,3 & 270,2 & 155,1 & 144,4 & 116,7 \\
\hline & & Ambiente & Periférica & 241,4 & 218,0 & 178,7 & 300,2 & 346,5 \\
\hline & & & Central & 212,1 & 220,3 & 176,7 & 142,0 & 177,1 \\
\hline & \multirow[t]{3}{*}{ Atlantic } & & & & & & & \\
\hline & & Refrigerado & Periférica & 241,4 & 202,4 & 217,2 & 220,6 & 302,9 \\
\hline & & & Central & 212,1 & 236,0 & 174,0 & 212,0 & 234,8 \\
\hline
\end{tabular}

(1) dados médio de quatro tubérculos

açúcares redutores pelo método de Somogyi-Nelson (Nelson, 1944; Hodge \& Hofreiter, 1962). Os teores de sacarose foram determinados por meio da reação com antrona fria, após a adição de KOH (Passos, 1996).

Cada experimento foi conduzido em delineamento inteiramente casualizado no esquema fatorial $(2 \times 2 \times 5)$, sendo dois genótipos, duas regiões dos tubérculos (central - região medular do tubérculos e periférica - região a $+/-1 \mathrm{~cm}$ da casca) e cinco épocas de coleta, com quatro repetições, considerando-se cada tubérculo como unidade experimental.

\section{RESULTADOS E DISCUSSÃO}

De forma geral os teores de amido não foram alterados pela temperatura de armazenamento pós-colheita, enquanto os demais carboidratos analisados apresentaram aumento nos teores, quando os tubérculos foram submetidos à refrige- ração, principalmente entre 10 e 20 dias de armazenamento.

Os teores de amido, nos tubérculos do plantio de outono (Tabela 1) apresentaram um padrão de variação semelhante entre as cultivares, regiões e condições de armazenamento. Destacandose aos 40 dias de armazenamento maiores teores de amido nos tubérculos da cv. Atlantic, mantidos à temperatura ambiente, independente da região, diferindo dos armazenados sob refrigeração (Tabela 1). Nos tubérculos da cv. Atlantic mantidos sob refrigeração, em comparação aos armazenados no ambiente, foi verificado um acúmulo preferencial de amido na região periférica.

Para o plantio de primavera, os teores de amido (Tabela 1) em cada cultivar apresentaram-se pouco influenciados pela temperatura e pelo tempo de armazenamento. Aos 40 dias de armazenamento, os teores de amido dos tubérculos das cultivares Pérola e Atlantic, foram maiores na região periférica, em ambas condições de armazenamento.

Os teores de carboidratos solúveis totais (Figura 1) das duas cultivares foram mais elevados sob refrigeração do que em condição ambiente. Sob refrigeração, na região central dos tubérculos da 'Pérola' ocorreram dois pontos de aumento nos teores de carboidratos solúveis totais entre 0 e 10 dias e entre 30 e 40 dias de armazenamento (Figura 1A), nas demais condições os teores de carboidratos solúveis totais aumentaram até 20 dias de armazenamento, com posterior manutenção. Para a região periférica dos tubérculos de ambas as cultivares sob refrigeração, a elevação nos teores de carboidratos solúveis totais ocorreu até os 30 dias de armazenamento, com posterior declínio. Aos 40 dias de armazenamento sob refrigeração, os carboidratos solúveis totais da 'Pérola' e 'Atlantic' do plantio de outono concentraram-se preferencial- 


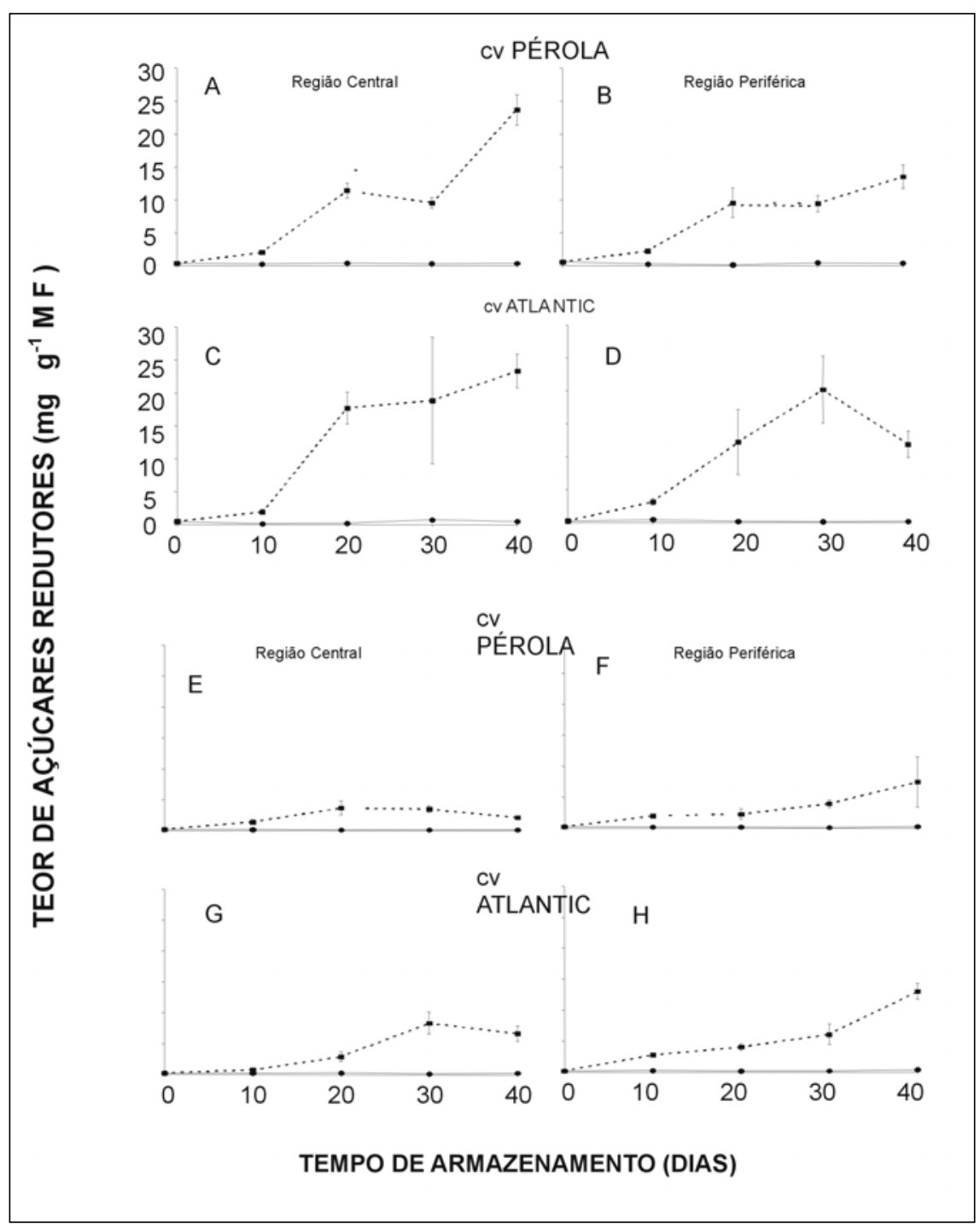

Figura 2. Teor de açúcares redutores em tubérculos de batata das cvs Pérola e Atlantic, oriundos dos plantios de outono/99 (A, B, C e D) e primavera/99 (E, F, G, e H), em função do tempo e das condições de armazenamento, [ ambiente ( 3/43/4) e refrigeração ( - - - ) ]. A barra indica o desvio padrão da média. Pelotas, UFPEL, 1999.

mente na região central, ao passo que sob temperatura ambiente o acúmulo foi similar em ambas regiões (Figura 1).

Os tubérculos da cultivar Pérola de primavera, sob refrigeração, independente da região, não acumularam elevados teores de carboidratos solúveis totais quando comparados com os da cv. Atlantic (Figura 1). Entre os plantios de primavera (Figura $1 \mathrm{G}$ e $\mathrm{H}$ ) e outono (Figura 1C e D) a cultivar Atlantic apresentou um padrão de acúmulo similar, sendo intensificado na refrigeração.

Aos 40 dias de armazenamento, os teores de carboidratos solúveis totais nos tubérculos da cultivar Pérola submetidos à refrigeração (Figura 1E e F) foram maiores na região periférica. $\mathrm{Na} c \mathrm{c}$.
Atlantic (Figura $1 \mathrm{G} \mathrm{e} \mathrm{H}$ ), independente da condição de armazenamento, os teores de carboidratos solúveis totais foram semelhantes nas duas regiões.

Os teores de sacarose (Tabela 2) também aumentaram, quando os tubérculos foram mantidos sob refrigeração. Nas duas cultivares ocorreu um incremento entre 0 e 10 dias de armazenamento, sendo que em 'Pérola' houve outro entre os 30 e 40 dias, na região central, e entre 20 e 30 dias, na região periférica. Os teores de sacarose dos tubérculos da cultivar Pérola, do plantio de outono, armazenados sob refrigeração, aos 40 dias, concentraramse preferencialmente na região central. Nos tubérculos de 'Atlantic' armazena- dos em condição ambiente, os teores de sacarose foram significativamente mais elevados na região periférica.

Para os teores de sacarose nos tubérculos do plantio de primavera (Tabela 2), verificou-se um comportamento similar quanto ao padrão de acúmulo, com os resultados descritos para carboidratos solúveis totais, ou seja, a cultivar Pérola, independente da região, não teve os teores altamente intensificados pela refrigeração, sendo menores nos tubérculos do plantio de primavera do que nos do plantio de outono. Destaca-se, também, para a cultivar Pérola uma redução nos teores de sacarose entre 30 e 40 dias de armazenamento, sendo que aos 40 dias não foi verificada diferença entre as condições de armazenamento, independente da região do tubérculo. Aos 40 dias de armazenamento destaca-se dentro de cada cultivar nenhum efeito de alocação preferencial de sacarose entre as regiões, porém verifica-se que os tubérculos da cv. Atlantic apresentaram maiores teores de sacarose que os da Pérola.

Os teores de açúcares redutores apresentaram-se mais elevados quando os tubérculos foram armazenados sob refrigeração, principalmente após 10 dias de armazenamento, sendo o padrão de variação semelhante dentro de cada cultivar. Aos 40 dias de armazenamento, sob refrigeração, os teores de açúcares redutores das cultivares Pérola (Figura 2A e B) e Atlantic (Figura 2C e D), do plantio de outono, concentraram-se preferencialmente na região central, contudo sob temperatura ambiente foram similares em ambas regiões.

Os teores de açúcares redutores nos tubérculos de plantio de primavera (Figura 2), apresentaram variações similares aos dos carboidratos solúveis totais, destacando-se maior efeito da refrigeração. Contudo, para a região periférica dos tubérculos da cv. Atlantic (Figura $2 \mathrm{H})$, os teores de açúcares redutores apresentaram incrementos constantes de 0 até 30 dias de armazenamento, o mesmo não aconteceu na região periférica (Figura 2G). Aos 40 dias, os teores de açúcares redutores dos tubérculos da cultivar Pérola (Figura 2E e F) foram maiores na região periférica sob refrigeração, tal fato se repetiu para a cv. 
Tabela 2. Teor de sacarose ( $\mathrm{mg} \mathrm{g}^{-1}$ massas fresca) de tubérculos de duas cultivares batata colhidos em duas épocas de plantios e armazenados sob duas condições de temperatura. Pelotas, UFPEL, 1999.

\begin{tabular}{|c|c|c|c|c|c|c|c|c|}
\hline \multirow{3}{*}{ Plantio } & \multirow{3}{*}{ Cv. } & \multirow{3}{*}{$\begin{array}{l}\text { Condição de } \\
\text { armazenam. }\end{array}$} & \multirow{3}{*}{$\begin{array}{l}\text { Região do } \\
\text { tubérculo }\end{array}$} & \multicolumn{5}{|c|}{ Tempo de armazenamento (dias) } \\
\hline & & & & 0 & 10 & 20 & 30 & 40 \\
\hline & & & & \multicolumn{5}{|c|}{ Teor de sacarose ( $\mathrm{mg} \mathrm{g}^{-1}$ massa fresca) } \\
\hline \multirow{10}{*}{ Outono } & \multirow{5}{*}{ Pérola } & \multirow[t]{2}{*}{ Ambiente } & Periférica & 3,0 & 3,8 & 1,6 & 7,6 & 3,1 \\
\hline & & & Central & 2,6 & 3,0 & 3,5 & 3,9 & 2,8 \\
\hline & & & & & & & & \\
\hline & & \multirow[t]{2}{*}{ Refrigerado } & Periférica & 3,0 & 13,1 & 7,4 & 16,8 & 12,0 \\
\hline & & & Central & 2,6 & 7,8 & 9,0 & 9,7 & 16,1 \\
\hline & \multirow{5}{*}{ Atlantic } & \multirow[t]{2}{*}{ Ambiente } & Periférica & 3,1 & 3,5 & 2,6 & 4,9 & 8,1 \\
\hline & & & Central & 1,8 & 3,9 & 1,3 & 3,4 & 6,2 \\
\hline & & & & & & & & \\
\hline & & \multirow[t]{2}{*}{ Refrigerado } & Periférica & 3,1 & 10,8 & 9,9 & 8,7 & 9,9 \\
\hline & & & Central & 1,8 & 7,2 & 7,4 & 10,7 & 9,4 \\
\hline \multirow{10}{*}{ Primavera } & & \multirow[t]{2}{*}{ Ambiente } & Periférica & 3,0 & 1,8 & 2,7 & 3,1 & 2,6 \\
\hline & \multirow{4}{*}{ Pérola } & & Central & 3,0 & 2,7 & 3,2 & 3,8 & 2,1 \\
\hline & & & & & & & & \\
\hline & & \multirow[t]{2}{*}{ Refrigerado } & Periférica & 3,0 & 7,0 & 5,4 & 3,8 & 3,8 \\
\hline & & & Central & 3,0 & 7,2 & 5,6 & 7,1 & 3,7 \\
\hline & \multirow{5}{*}{ Atlantic } & \multirow[t]{2}{*}{ Ambiente } & Periférica & 2,4 & 3,2 & 2,0 & 1,8 & 2,3 \\
\hline & & & Central & 2,5 & 2,9 & 3,5 & 2,4 & 3,2 \\
\hline & & & & & & & & \\
\hline & & \multirow{2}{*}{ Refrigerado } & Periférica & 2,4 & 10,7 & 12,0 & 10,2 & 10,9 \\
\hline & & & Central & 2,5 & 7,8 & 13,6 & 9,7 & 9,9 \\
\hline
\end{tabular}

(1) dados médio de quatro tubérculos

Atlantic (Figura $2 \mathrm{G} \mathrm{e} \mathrm{H}$ ).

Aparentemente, a distribuição dos assimilados em direção à região periférica ocorre porque esta é uma zona meristemática, onde a respiração se dá de forma mais intensa, estando relacionada à promoção da brotação. O acúmulo de carboidratos na região central pode ser devido à ressíntese de compostos para a manutenção celular, ou devido à redistribuição de metabólitos entre o citossol e o amiloplasto, como sugerido por Ohad et al. (1971).

A distribuição diferenciada de carboidratos não estruturais entre regiões (fonte e dreno), caracteriza uma competição por assimilados, visto que teores elevados em uma região, proporcionavam baixos acúmulos em outra (Sonnewald et al., 1997). A competitividade espacial por carboidratos ocorreu em função de processos metabólicos celulares. Desta forma, a região periférica pode ser consi- derada como um dreno em relação à região central.

As diferenças nos teores de açúcares e na sua distribuição entre as regiões e as épocas de colheitas foram, provavelmente decorrentes das variações sazonais a que estiveram expostas as plantas durante o crescimento e formação dos tubérculos. Os tubérculos do plantio outono desenvolveram-se em condições de baixas temperaturas e fotoperíodos decrescentes. Ao contrário, durante o cultivo de primavera, os tubérculos cresceram sob temperaturas e fotoperíodos ascendentes, variações estas que podem ter influenciado a partição de energia entre a respiração de crescimento e de manutenção dos tecidos dos tubérculos.

Ao final do período de armazenamento os tubérculos do plantio outono apresentaram teores de carboidratos não estruturais diferenciados entre as cultivares, quando subme- tidos às duas condições de armazenamento. Sob refrigeração, os teores de açúcares redutores e solúveis totais, amido e sacarose em geral foram maiores nos tubérculos da cultivar Pérola, mas sob temperatura ambiente, estes teores foram mais elevados nos tubérculos da cultivar Atlantic.

Os teores de carboidratos dos tubérculos da primavera foram mais elevados na cultivar Atlantic do que na Pérola, tanto sob refrigeração quanto em condições de ambiente, com exceção da concentração de açúcares solúveis totais, em condições ambiente.

Os tubérculos da cv. Pérola apresentaram maiores variações nos teores de carboidratos solúveis não estruturais entre os períodos de plantio e, portanto, parecem ser mais sensíveis ao frio. Assim, quando, os tubérculos são expostos a temperaturas mais baixas no campo e posteriormente, colocados sob refrigeração, tem potencializada a ação de 
enzimas previamente ativadas pelo frio do período de cultivo. Esta alteração fisiológica está de acordo com van Berkel et al. (1994), os quais afirmam que as baixas temperaturas nos tubérculos de batata induzem ao acúmulo de um novo mRNA e proteínas junto com o aumento de mensagens genéticas pré-existentes.

Os teores de açúcares não estruturais foram influenciados pelas condições de armazenamento dos tubérculos (temperatura), pela cultivar e pela época de plantio das plantas (condições de exposição das plantas no campo). Estes resultados mostram que a adaptabilidade de uma cultivar para o processamento depende não só da sua qualidade na colheita, mas também da sua resposta às condições de armazenamento (Duplessis et al., 1996).

A variação nos teores de sacarose está em concordância com o trabalho de Duplessis et al. (1996). Tais pesquisadores sugerem que as condições de baixa temperatura originam o acúmulo de ATP no tecido de batata. Este acúmulo de ATP parece ativar respiração resistente ao cianeto que diminui os níveis de ATP e simultaneamente aumenta as concentrações de sacarose, tornando-a substrato da invertase ácida vacuolar que origina o acúmulo de açúcares redutores (Duplessis et al., 1996). Sabese que além do frio, fatores como degradação do amido, exportação de açúcar para o amiloplasto ou biossíntese de sacarose, podem ser responsáveis pelo acúmulo total de açúcares solúveis em tubérculos de batata (Zrenner et al. 1996).

Os resultados deste estudo permitem concluir que os teores de amido localizam-se preferencialmente na região periférica dos tubérculos, e os demais carboidratos distribuem-se diferentemente segundo o genótipo, a temperatura de armazenamento e a época de plantio. Os teores de carboidratos não estruturais aumentam quando os tubérculos são submetidos à refrigeração, com exceção dos teores de amido. A refrigeração incrementa os teores de carboidratos não estruturais dos tubérculos da cv. Pérola de forma mais acentuada no plantio de outono, enquanto que na cv. Atlantic essa elevação ocorre independente do período de plantio.

\section{LITERATURA CITADA}

BARKER, J. Studies in the respiratory and carbohydrate metabolism of plant tissues. XXIV. The influence of a decrease in temperature on the contents of certain phosphate esters in plant tissues. New Phytologist, Oxford, v. 67, p. 487493, 1968.

BURTON, W.G. Post-harvest physiology of food crops. London: Longman, 1982. 339 p.

BURTON, W.G. The Potato. Harlow: Longman Scientific and Technical, 1989. 742 p.

CLEGG, K.M. The application of the anthrone reagent to the estimation of starch in cereals. Journal of Science Food Agricultural, v. 3, p. 4044. 1956.

DAVIES, H.V.; VIOLA, R. Regulation of sugar accumulation in stored potato tubers. Postharvest News and Information, Oxon, v. 3, p. 97-100, 1992.

DUPLESSIS, P.M.; MARANGONI, A.G.; YADA, R.Y. A mechanism for low temperature induced sugar accumulation in stored potato tubers: The potential role of the alternative pathway and invertase. American Potato Journal, v. 73, p. 483494, 1996.

HODGE, J.E.; HOFREITER, B.T. Analysis and preparation of sugars. In: WHISTLER, R.L.; WOLFROM, M.L. (eds.), Methods in carbohydrate chemistry, v. 1. New York: Academic Press, 1962. p. 356-378.

ILLEPERUMA， C.; SCHLIMME， D.; SOLOMOS, T. Changes in sugars and activities of sucrose phosphate synthase, sucrose synthase, and invertase during potato tuber (russet burbank) reconditioning at $10^{\circ} \mathrm{C}$ in air and $2.53 \mathrm{kPa}$ oxygen after storage for 28 days at $1{ }^{\circ} \mathrm{C}$. Journal American Society Horticultural Science, v. 123, p. 311-316, 1998.

ISHERWOOD, F.A. Starch-sugar interconversion in Solanum tuberosum. Phytochemistry, v. 12, p. 2579-2591, 1973.

ISHERWOOD, F.A. Mechanism of starch-sugar interconversion in Solanum tuberosum. Phytochemistry, v. 15, p. 33-41, 1976.

McCREADY, R.M., GUGGOLZ, J.; WENS, H.S. Determination of starch and amylase in vegetables. Analytical Chemistry, v. 22, p. 1156-1158, 1950. MELO, P.E. Cultivares de batata potencialmente úteis para o processamento na forma de fritura no Brasil e manejo para obtenção de tubérculos adequados. Informe Agropecuário, Belo Horizonte, v. 20, p. 112-119, 1999.
NELSON, N.A. A photometric adaptation of the Somogyi method for the determination of glucose. Journal of Biology Chemistry, v. 153, p. 375-380, 1944.

OHAD, I.; FRIEDBERG, I.; NE'MAN, Z.; SCRAMM, M. Biogenesis and degradation of starch. I. The fate of the amyloplast membrane during maturation and storage of potato tubers. Plant Physiology, v. 47, p. 465-477, 1971.

PASSOS, L.P. Métodos analiticos e laboratoriais em fisiologia vegetal. Coronel Pacheco: Embrapa Gado de Leite, 1996. 223 p.

PEREIRA, A.S.; COSTA, D.M.; VENDRUSCOLO, J.L.S.; DANIELS, J.; CHOER, E.; AUGUSTIN, E.; FORTES, G.R.L.; BERTONCINI, O.; HIRANO, E.; GOMES, C.B. BRS Pérola: cultivar de batata adaptada a sistema de produção de pequenos produtores, para processamento de "batata palha". Agropecuária Clima Temperado, Pelotas, v. 2, n. 2, p. 287-290, 2000.

SOLOMOS, T.; LATIES, G.G. The mechanism of ethylene and cyanide action in triggering the rise in respiration in potato tubers. Plant Physiology, Rockville, v. 54, p. 506-511, 1975.

SONNEWALD, U.; HAJIREEEZAEI, M.R.; KOSSMANN, J.; HEYER, A.; TRETHEWEY, R.N.; WILLMITZER, L. Increased potato tuber size resulting from apoplastic expression of a yeast invertase. Nature Biotechnology, v. 15, p. 794-797, 1997.

SOWOKINOS, J. Stress induced alterations in carbohydrate metabolism. In: VADA, M.E.; PARK, W.D. (eds.). The molecular and cellular biology of the potato. Wallingford: C.A.B. International, 1990. $137 \mathrm{p}$.

van BERKEL, J.; SALAMINI, F.; GEBHARDT, C. Transcripts accumulating during cold storage of potato (Solanum tuberosum L.) tubers are sequence related to stress-responsive genes. Plant Physiology, v. 104, p. 445-452, 1994.

VLIET, W.F.; van SCHRIEMER, W.H. The sugar accumulation of potatoes kept at low temperature, as studied in a small selection of samples of Dutch varieties. European Potato Journal, v. 3, p. 263271, 1960.

ZHOU, D.; SOLOMOS, T. Effect of hypoxia on sugar accumulation, respiration, activities of amylase and starch phosphorylase, and induction of alternative oxidase and acid invertase during storage of potato tubers (Solanum tuberosum cultivar Russet Burbank) at $1{ }^{\circ} \mathrm{C}$. Physiologia Plantarum, v. 104, p. 255-265, 1998.

ZRENNER, R.; SCHÜLER, K.; SONNEWALD, U. Soluble acid invertase determines the hexoseto-sucrose ratio in cold-stored potato tubers. Planta, v. 198, p. 246-252, 1996. 